\title{
The central European floods of August 2002: \\ Part 1 - Rainfall periods and flood development
}

\author{
Uwe Ulbrich, Tim Brücher, Andreas H. Fink, Gregor C. Leckebusch, \\ Andreas Krüger and Joaquim G. Pinto \\ Institute for Geophysics and Meteorology, University of Cologne, Germany
}

Record-breaking rainfall amounts and intensities were observed at several raingauges in central Europe during the first half of August 2002 (Fig. 1). They produced flash floods in small rivers in the Erz Mountains, the Bohemian Forest and in Lower Austria (see Fig. 2), followed by record-breaking floods of larger rivers fed from these areas. The Vltava submerged parts of the city of Prague on 13-15 August, and subsequently the Elbe flooded parts of Dresden and further villages and towns located downstream. The gauge level of $9.40 \mathrm{~m}$ measured at Dresden on 17 August 2002 is the highest level since 1275, exceeding the former maximum level of $8.77 \mathrm{~m}$ recorded in 1845 (Grollmann and Simon 2002). Parts of the Danube catchment were also affected by severe flooding. There were 100 fatalities connected with the floods in central Europe, and the economic loss is estimated at 9 billion Euros for Germany (German government's estimate), 3 billion Euros for Austria, and 2.5 billion Euros for the Czech Republic (estimates from Boyle 2002). The event thus replaced the European winter storm Lothar of December 1999 (Ulbrich et al. 2001) as the most expensive weather-related catastrophe in Europe in recent decades (see Cornford 2002). In this study, we give an overview of the exceptional rainfall experienced over wide areas on 12/13 August 2002, and the resulting floods. Further events during early August 2002, in particular the event on 6/7 August in Lower Austria, are briefly mentioned.

Flash floods arising from rainfall on 12 August 2002

We will initially focus on the river catchments located on the northern slopes of the Erz Mountains south of Dresden which were particularly hit by flash floods on 12/13 August. The narrow flood plains of the Rivers Müglitz, Weißeritz and Mulde (Fig. 2) are located in a mainly forested area, with gneiss and mica slate bedrock beneath the surface layer. The village of Weesenstein on the banks of the small River Müglitz was particularly hit by a flash flood. At the Dohna gauging station, located just $2 \mathrm{~km}$ downstream of Weesenstein, water levels rose by $1 \mathrm{~m}$ between 0930 and 1030 LT (local time - Central European Summer Time, which is GMT +2 hours) on 12 August 2002, and continued to climb at a rate of about $0.5 \mathrm{mh}^{-1}$ until the telemetry transmissions failed after $1545 \mathrm{LT}$ at a level of $3.57 \mathrm{~m}$. According to press reports (Smoltczyk 2002) the Müglitz continued to rise throughout the afternoon (typical levels during previous days were about $0.2 \mathrm{~m}$ ). Runoff was enhanced when the dam of an upstream flood-retention reservoir broke at about 1800 LT. The flood remained at record levels for about 10 hours throughout the night, destroying a quarter of the 40 houses of the village of Weesenstein. More than 24 hours later, at about $1600 \mathrm{LT}$ on 14 August 2002, the waters of the River Müglitz were still running through its former main street (Fig. 3, p. 391).

The severity of the flash flood of the Müglitz can be understood by examining 10-minute rainfall records for the synoptic station of Zinnwald-Georgenfeld (altitude $882 \mathrm{~m}$ above sea-level (a.s.1.)), which is located in the headwaters near to the catchment divide. Intense precipitation was first measured after 0400 LT (Fig. 4), followed by a sequence of intense rainfall peaks of more than $9 \mathrm{~mm}$ within 10 


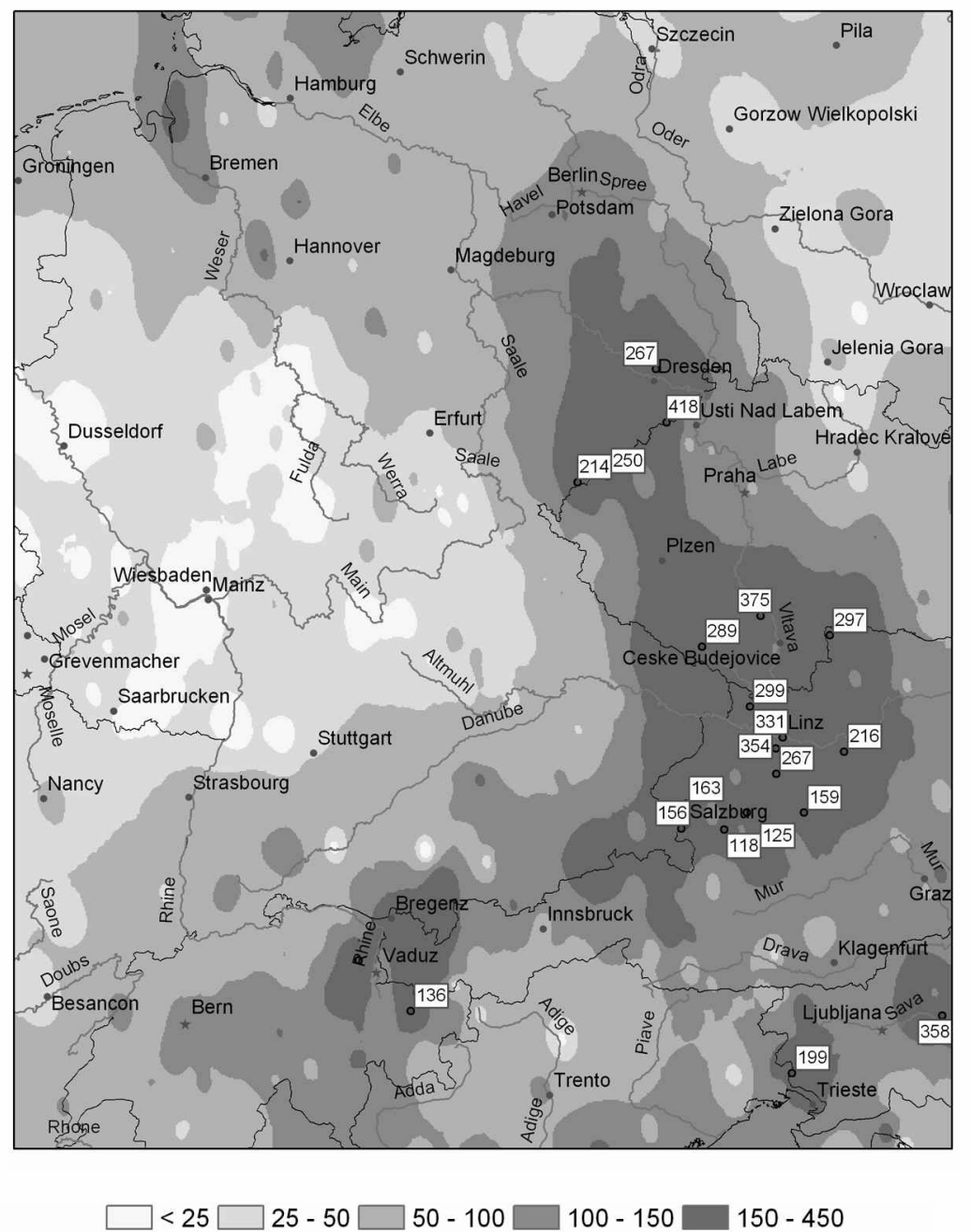

Fig. 1 Precipitation totals (shading, $\mathrm{mm}$ ) and percentage values of mean monthly precipitation (station values in white boxes) for August (reference period 1961-90) for accumulated rainfall from 0800 LT on 1 August 2002 to 0800 LT on 13 August 2002. (Courtesy of B. Rudolf, Global Precipitation and Climate Centre and Deutscher Wetterdienst, Offenbach, Germany.)

minutes. According to Bartels et al. (1997) such intensities have an estimated return period of about 1 year in this area and are thus not unusual. After 1000 LT precipitation characteristics changed into a more steady rainfall. At that time (i.e. just over 6 hours after the first peak) the accumulated rainfall total had already exceeded $120 \mathrm{~mm}$ - a 12-hour total which is expected to be exceeded only once in 100 years (Bartels et al. 1997). A total of $312 \mathrm{~mm}$ of rain within 24 hours was reported for the time period between 0600 GMT on 12 August and 0600 GMT on 13 August. This is about three times the mean monthly rainfall for
August at Zinnwald, and the highest amount of daily precipitation ever measured in Germany (Deutscher Wetterdienst 2002). The old record of $260 \mathrm{~mm}$ was set at Zerlhain (Saxonia) in June 1906. Figure 4 also shows the record at Fichtelberg (altitude $1215 \mathrm{~m}$ a.s.1.), located south of Chemnitz, about $70 \mathrm{~km}$ south-west of Zinnwald. Rainfall characteristics are similar, but the intensities are lower. This area is part of the catchment of the River Mulde, which drains northwards, broadly parallel to the Elbe, until both rivers merge near Dessau. Towns along the Mulde were also hit by severe floods following the rainfall events. 




Fig. 2 Central Europe showing orography, and the relevant river network as well as geographical names mentioned in the text

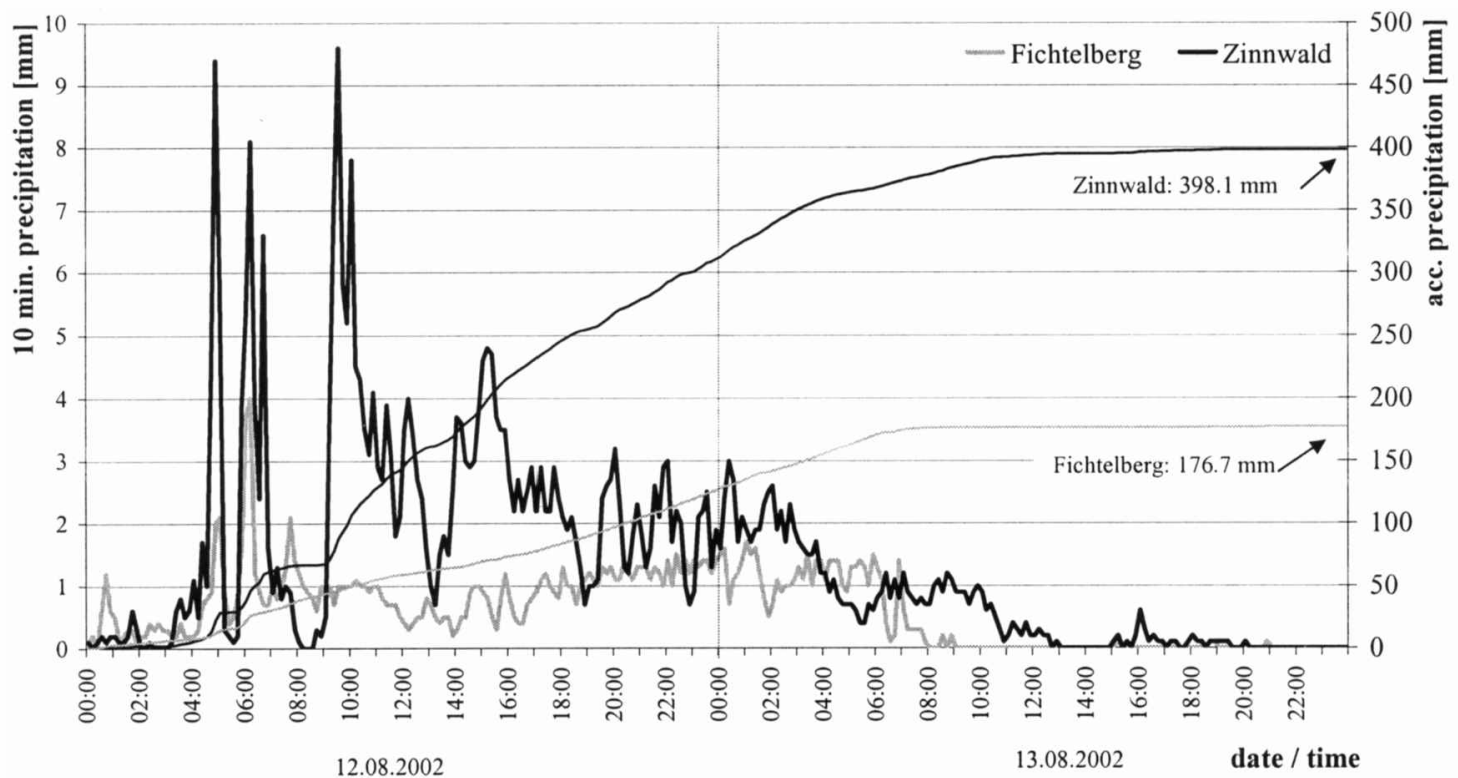

Fig. 4 10-minute averages of precipitation on 12 and 13 August 2002 at Zinnwald (black) and Fichtelberg (grey), together with accumulated totals. Times are local time. 
While rainfall was particularly extreme on the north-eastern slopes of the Erz Mountains, extraordinary amounts of precipitation were also observed further south in the western Czech Republic, south-eastern Germany, and north-eastern Austria. Precipitation amounts of $104 \mathrm{~mm}$ observed at Waldkirchen (in the Bavarian Forest, Germany) on 12 August, for example, have an estimated return period of 100 years (Bavarian Water Board 2002a). The torrential rains in this area resulted in a flood in the River Regen (a westward-flowing leftbank tributary of the Danube) reaching peak levels corresponding to a return period of 100300 years. Even further south, rainfall of more than $100 \mathrm{~mm}$ in 24 hours in the north-eastern Austrian Alps led to a very rapid flow increase in the River Salzach (a right-bank tributary of the Inn, which merges with the Danube at Passau). At Salzburg, gauge heights increased from about 4.5 to $8.0 \mathrm{~m}$ within 12 hours. The peak was reached in the afternoon of 12 August when the flow reached $2300 \mathrm{~m}^{3} \mathrm{~s}^{-1}$, a value not observed since 14 September 1899 (Wiesenegger 2002). Extreme rainfall was also observed in the Bavarian Alps. A subsequent inundation of parts of Munich by the Isar was only prevented through the recently increased capacity of the Sylvenstein reservoir which is located upstream (Bavarian Water Board 2002b).

\section{The Elbe flood wave}

The extreme flow rates in many tributaries of the Elbe and Danube subsequently led to major floods in both rivers. The Danube flood produced damage between the German-Austrian border and Vienna (Grollmann and Simon 2002), but data available to the authors are insufficient to provide a satisfactory description of the flood wave. We will thus focus on the Elbe flood in Germany. Downstream of the Erz Mountains the river bed is located in a broad glacial valley with gravel and sand beneath the surface, $10-25 \mathrm{~m}$ thick in the Dresden area (Sächsisches Landesamt für Umwelt und Geologie 2003). Grassland dominates along the river banks.

Figure 5 shows the Elbe flood wave. At Usti nad Labem (close to the Czech-German border), streamflow initially increased from 9 to 11 August. This first small wave can be assigned to large precipitation amounts that affected the southern parts of the Czech Republic, south-east Germany, and north-east Austria on 6/7 August (the precipitation event and its consequences are described in more detail later in this paper). After a first peak during 11 August $\left(1100 \mathrm{~m}^{3} \mathrm{~s}^{-1}\right)$ the water amounts decreased until the morning of the next day (streamflow below $1000 \mathrm{~m}^{3} \mathrm{~s}^{-1}$ ). Rainfall in the Erz Mountains region and in western parts of the Czech Republic commenced during 11/12 August. First the more local and then the more remote sources contributed to the main Elbe flood wave. A main contribution to the Elbe flood originated from the River Vltava, which inundated the city of Prague between 13 and 15 August. A return period of 500 years is estimated for the flood levels at Prague (Grollmann and Simon 2002). The Elbe flood crest reached Usti in the evening of 16 August, and Dresden in the morning of the 17th (Fig. 5). By this time the River Elbe had inundated several historical buildings in Dresden. Other parts of Dresden, such as the central railway station, were flooded by the River Weißeritz - the catchment drained by this tributary of the Elbe is located between those of the Müglitz and Mulde (Fig. 2). Even though the Elbe flood wave appears as a rather sharp peak in Fig. 5, it was not until 22 August that streamflow returned to values below $1000 \mathrm{~m}^{3} \mathrm{~s}^{-1}$. The flood caused a strong rise of groundwater levels in the immediate vicinity of the Elbe due to infiltration through the floodplain gravels in Dresden (Sächsisches Landesamt für Umwelt und Geologie 2003). A rise of up to $6 \mathrm{~m}$ (exceeding the previous records by up to $3 \mathrm{~m}$ ) led to a flooding of basements in areas beyond the extent of the direct fluvial flooding. During the downstream progress of the flood wave there is a steady attenuation (Fig. 5) due to retention in the flood plains. Large sudden reductions of streamflow peaks originate from breaches in the Elbe embankment, while increases can be assigned to the contributions of tributaries, in particular of the Mulde (Engel 2002). More than ten bank breaches occurred, many of them in the area of Wittenberg. They led to a local reduction of 


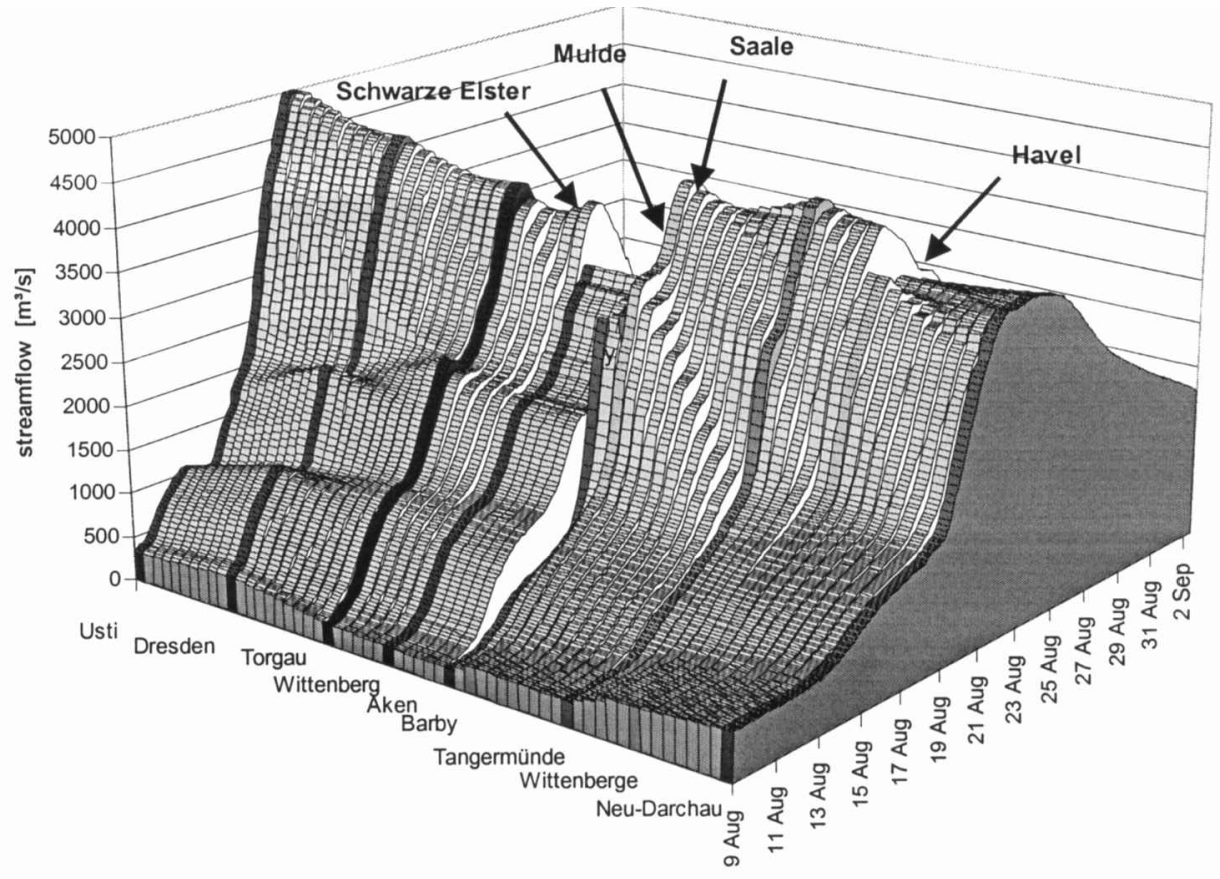

Fig. 5 Development of the surge of the River Elbe, based on discharge rates at several gauge locations. Left to right is downstream. (Courtesy of H. Engel and W. Wiechmann, Bundesanstalt für Gewässerkunde, Koblenz, Germany.)

streamflow of more than $500 \mathrm{~m}^{3} \mathrm{~s}^{-1}$ or $10 \%$ (Engel 2002) at this gauge. Controlled flooding of areas near the Havel estuary reduced the flood wave by about 75 million $\mathrm{m}^{3}$. Engel (2002) suggests that a favourable timing both of dyke breaks and of the intentional flooding of retention areas significantly reduced the flood wave further downstream. Thus, the return periods of peak streamflow at downstream locations are clearly below 100 years, while they exceeded 200 years at Usti and Dresden (Engel 2002).

\section{Further extreme rainfall events during the first half of August 2002}

The extreme rainfalls on 11-13 August 2002 and the subsequent flooding were not unique during the first half of this month. Extreme precipitation amounts associated with widespread thunderstorm activity - characterised by large variations in rainfall intensity - in a belt extending from northern Germany to Austria had already been observed early in August 2002. Precipitation sums from the first 12 days of August amounted to some $150 \%$ of the aver- age August rainfall in parts of northern Germany (North Sea and Baltic Sea coasts, see Fig. 1) (Deutscher Wetterdienst 2002). On 6 and 7 August, there was a first large-scale rainfall event in central Europe. It affected a region encompassing the south-western part of the Czech Republic, Lower Austria, and southeastern Germany.

More than $100 \mathrm{~mm}$ of rain was observed at several weather stations in eastern Bavaria. In spite of the fact that these amounts have return periods of 50-100 years, they did not cause major flood waves due to the low antecedent river flows and still unsaturated soils (Bavarian Water Board 2002a). For Lower Austria, however, the local intensities and their consequences were much larger. At Zwettl-Stift, located in the Waldviertel ('forest quarter') about $250 \mathrm{~mm}$ fell during 6 and 7 August, with maximum intensities occurring around 2200 GMT on 6 August and during the afternoon of 7 August (Gutknecht et al. 2002). They led to a peak discharge of the River Kamp (of about $800 \mathrm{~m}^{3} \mathrm{~s}^{-1}$ ) with an estimated return period of several thousand years (Gutknecht et al. 2002). 


\section{Concluding remarks}

The first two weeks of August 2002 were characterised by extreme rainfall events in central Europe. Two events (6/7 and 12/13 August) caused severe flooding, in particular in smaller catchments in the Waldviertel (Lower Austria, former event) and in the Erz Mountains (latter event). Precipitation sums for the first half of August clearly exceeded the respective monthly average values in a belt from northern Germany to Austria. A new record for Germany with respect to 24 -hour totals $(312 \mathrm{~mm})$ was set at Zinnwald weather station. The individual peak 10-minute rainfall amounts at the same station are, however, not uncommon. Due to the duration of intensive rainfall, severe flooding of the Rivers Danube and Elbe was induced. The floods produced economic losses exceeding those of the winter storm of December 1999 (Lothar) which was previously the most expensive weather event in Europe. The river level at Dresden rose to a new record height, exceeding the peak of 1845 - when snowmelt and an ice dam were both contributory factors. This should not detract from the fact that summer floods are relatively common in central Europe. They are usually associated with a typical track of cyclones known among German meteorologists as the 'Vb-track'. In a subsequent companion paper we will describe the specific synoptic conditions that led to the two main events (6/7 and 12/13 August), discuss similarities with recent floods of neighbouring rivers (the Odra in 1997, the Vistula in 2001), and relate the events to results from model simulations of greenhouse gas-induced climatic change.

\section{Acknowledgements}

We wish to thank H. Engel and W. Wiechmann of the German Federal Institute of Hydrology (Koblenz) for providing Fig. 5 and for their readiness in replying to our questions; the Saxonian State Office for Environment and Geology (Dresden) for providing the gauge level data for Dohna and a preprint of the report on the groundwater effects of the floods; B. Rudolf of the Global Precipitation and Climate Centre (Offenbach) for providing Fig.
1; and Deutscher Wetterdienst (the German Weather Service) for providing the 10-minute rainfall measurements. We also thank $M s \mathrm{R}$. Lauber for providing the picture of Weesenstein (Fig. 3). The work was supported by the EU project MICE (Modelling the Impacts of Climate Extremes) under grant EVK2-CT2001-00118.

\section{References}

Bartels, H., Malitz, G., Asmus, S., Albrecht, F. M., Dietzer, B., Günther, T. and Ertel, H. (1997) Starkniederschlagshöhen für Deutschland, KOSTRA. Deutscher Wetterdienst, Offenbach

Bavarian Water Board (Bayerisches Landesamt für Wasserwirtschaft, Hochwassernachrichtendienst) (2002a) Hochwasser im August 2002, mit Berichtigungen vom 28.10.2002. Available online from http://www.bayern.de/lfw/hnd/hw110802/ titelseite.htm

- (2002b) Sylvensteinspeicher schützt erneut München vor Hochwasser-Überschwemmungen. Press release 14 August 2002, available online from http://www.bayern.de/lfw/aktuelles/presse/ 140802 sylvenstein.htm

Boyle, C. E. (2002) Eastern European floods cause widespread damage. Insur. f., September 2002, available from http://www.insurancejournal.com/ magazines / southcentral / 2002 / 09 / 16 / features / 23361. htm

Cornford, S. G. (2002) Human and economic impacts of weather events in 2001. Bull. World Meteorol. Organ., 51, pp. 257-277

Deutscher Wetterdienst (German Weather Service) (2002) Extreme precipitation amounts in central Europe from 1-13 August 2002. Available online from http://www.dwd.de/en/FundE/Klima/KLIS/ prod / spezial / regen / rr extreme 200208 germany. pdf

Engel, H. (2002) Das Augusthochwasser 2002 im Elbegebiet. Available online from http://www.bafg.de/ html/projekte/hydro/engel/ elbe2002.pdf

Grollmann, T. and Simon, S. (2002) Flutkatastrophen - Boten des Klimawandels. Z. Versicher., 53, pp. 682-689

Gutknecht, D., Reszler, C. and Blöschl, G. (2002) Fahrtausend-Hochwasser am Kamp? Available online from http://www.tuwien.ac.at/forschung/ nachrichten/a-kamp.htm

Sächsisches Landesamt für Umwelt und Geologie (2003) Einfluss des August Hochwassers 2002 auf das Grundwasser. Report available from Sächsisches Staatsministerium für Umwelt und Landwirtschaft, 01075 Dresden, Germany, available online from http://www.umwelt.sachsen.de/de/ 
wu/umwelt/lfug/lfug-internet/veroeffentlichungen/ verzeichnis/Wasser/HWBericht.pdf

Smoltczyk, A. (2002) Die Wasser von Weesenstein. Der Spiegel, 26 August, pp. 76-83

Ulbrich, U., Fink, A. H., Klawa, M. and Pinto, J. G. (2001) Three extreme storms over Europe in December 1999. Weather, 56, pp. 70-80

Wiesenegger, J. (2002) Das 100-jährliche Hochwasser am 12. August 2002. Available online from http:// www.salzburg.gv.at/themen/nuw/wasserwirtschaft/ 64-hydrographie/hochwasser.htm/hw-aug-2002. htm
The online documents referenced above are mirrored under http://www.meteo.uni-koeln.de/ content/forschung/klimadiagnose/floods.html

Correspondence to: Dr U. Ulbrich, Institute for Geophysics and Meteorology, University of Cologne, 50923 Köln, Germany. e-mail: ulbrich@ meteo.uni-koeln.de

(C) Royal Meteorological Society, 2003.

doi: 10.1256/wea.61.03A

\title{
An extreme precipitation event in southern Morocco in spring 2002 and some hydrological implications
}

\author{
Andreas H. Fink and Peter Knippertz
}

Institute of Geophysics and Meteorology, University of Cologne, Germany

Between 30 March and 1 April 2002, a heavy rainstorm crossed the region stretching from the hyper-arid north-western Sahara, across the arid southern foothills of the High Atlas, to the latter's main watershed. It caused exceptional precipitation totals (Table 1). The $72 \mathrm{~mm}$ at the Moroccan town of Ouarzazate (see location map in Fig. 1), recorded between 1800 GMT on 31 March and 1800 GMT on 1 April, corresponded to $62 \%$ of the annual average (Table 1) and to about seven times the average March rainfall. In contrast to the much wetter region north of the Atlas chain, only slightly more than 30 raindays $(>0.1 \mathrm{~mm})$ per year are observed at Ouarzazate and storms with totals of more than $25 \mathrm{~mm}$ are recorded less than once a year, displaying a large year-toyear variability (e.g. five years without a single intense storm between 1980 and 1985, but five storms between late 1987 and early 1989). The described event is the highest daily accumulation measured since at least September 1977. Among the detrimental effects of the intense precipitation event are flash floods, flooding of roads (Fig. 2(a)) and collapsing walls. The photo of the giant intermittent waterfall in the

Table 1 Accumulated precipitation (between 1800GMT on 30 March and 0000GMT on 2 April 2002) at considered stations with 3-hourly synoptic observations. Percentages of the respective annual averages are given for comparison.

\begin{tabular}{|c|c|c|c|c|c|c|c|}
\hline Name & $\begin{array}{l}\text { WMO } \\
\text { No. }\end{array}$ & Country & $\begin{array}{l}\text { Lat. } \\
\text { (N) }\end{array}$ & $\begin{array}{l}\text { Long. } \\
\text { (W) }\end{array}$ & $\begin{array}{l}\text { Height } \\
\text { (m) }\end{array}$ & $\begin{array}{l}\text { Accumulated } \\
\text { precipitation } \\
(\mathrm{mm})\end{array}$ & $\begin{array}{c}\% \text { of } \\
\text { annual } \\
\text { average }\end{array}$ \\
\hline Agadir & 60252 & Morocco & $30^{\circ} 20^{\prime}$ & $9^{\circ} 34^{\prime}$ & 23 & 13 & 5 \\
\hline Sidi Ifni & 60060 & Morocco & $29^{\circ} 22^{\prime}$ & $10^{\circ} 11^{\prime}$ & 66 & 26 & 18 \\
\hline Ouarzazate & 60265 & Morocco & $30^{\circ} 56^{\prime}$ & $6^{\circ} 54^{\prime}$ & 1140 & 72 & 62 \\
\hline Errachidia & 60210 & Morocco & $31^{\circ} 56^{\prime}$ & $4^{\circ} 24^{\prime}$ & 1042 & 31 & 25 \\
\hline Bechar & 60571 & Algeria & $31^{\circ} 37^{\prime}$ & $24^{\prime}$ & 816 & 13 & 15 \\
\hline Tindouf & 60656 & Algeria & $27^{\circ} 40^{\prime}$ & $8^{\circ} 08^{\prime}$ & 439 & 25 & 54 \\
\hline Bir Moghrein & 61401 & Mauritania & $25^{\circ} 14^{\prime}$ & $11^{\circ} 37^{\prime}$ & 364 & 11 & 26 \\
\hline
\end{tabular}

